\title{
The Importance of Various Indicators of Active Learning on the Enhancement of Saudi Students' Motivation and English Achievement: An Experimental Study
}

\author{
Oqab Alrashidi \\ ${ }^{1}$ School of Education, University of Ha'il, Ha'il, Saudi Arabia \\ Correspondence: Oqab Alrashidi, University of Ha’il, Saudi Arabia. E-mail: o.alrashidi@uoh.edu.sa
}

Received: Oct. 29, 2019

Accepted: Mar. 11, $2020 \quad$ Online Published: Mar. 16, 2020

doi:10.5430/elr.v9n1p40

URL: https://doi.org/10.5430/elr.v9n1p40

\begin{abstract}
This experimental study sought to examine the impact of four indicators of active learning (i.e., elaborated feedback, group work, situated learning, and videos and pictures in classroom instruction) on the enhancement of Saudi students' various motivational constructs (i.e., self-efficacy, task value, and effort expenditure) and English achievement. Participants were 289 university students, and the data were collected at three time points: Time 1 (before the intervention), Time 2 (in the middle of the intervention), and Time 3 (after the intervention). The findings of repeated measures ANOVA and follow-up $t$-tests revealed that the intervention had small impacts on all the variables at Time 2 (in the middle of the intervention). However, at Time 3 (after the intervention), the intervention had small impacts on effort expenditure and task value, a moderate impact on academic achievement, and a large impact on self-efficacy. In general, the evidence obtained provides important implications for educational practices and further research development.
\end{abstract}

Keywords: English learning, English teaching, active learning, motivation, Saudi Arabia

\section{Introduction}

English is widely considered as a global language because of its critical communication role in the fields of science, business, policy, the Internet, technology, popular entertainments, and even sports (British Council, 2013). An estimated one in four people around the world can speak English, and two billion people are expected to be learning and using English by the year 2020 (Tanielian, 2017). In a Harvard Business Review article, McCormick (2013) indicated that countries with better proficiency in English have better economies. Therefore, learning effective English is not simply for personal self-improvement, but may serve as an economic necessity in an increasingly interconnected world.

In recognition of the increasingly significant status of English, many countries around the world have chosen it as the first-rate foreign language to be taught in their educational institutions, and Saudi Arabia is no exception. English is a compulsory subject and is the only foreign language that is taught in public education. The Saudi Government perceives and views English as a major commodity which, upon capitalization, could facilitate economic growth and social development for the country as a whole. Despite the enormous effort that the Saudi Government has invested to improve the learning of English, students' English proficiency level remains inadequate and is below expectations when compared with other countries (Alhawsawi, 2013; Alrabai, 2016; Ur Rahman \& Alhaisoni, 2013).

A number of researchers (e.g., Al-Seghayer, 2014; Alkubaidi, 2014; Alrabai, 2014; Rajab, 2013) have attributed the low competence in English among Saudi students to different causes; like, the use of teacher-centred instruction, lack of real-world practice, students' reliance on memorization as a main strategy of learning, students' lack of encouragement and motivation, and teachers' dependence on the use of Arabic to teach English in classrooms. Indeed, it seems obvious that learning English in Saudi Arabia is an uninteresting feat. It is, therefore, important that researchers, from my point of view, focus on research inquiries that may enable understanding of the facilitation and promotion of quality teaching and effective learning of English in the context of Saudi Arabia for both students and educators, alike.

The current research study attempts to address the aforementioned issues and weaknesses in students' English learning by situating them within a motivational framework. The literature details the importance of various 
motivational factors, notably: (i) self-efficacy (e.g., Bandura, 1986, 1997; Pajares \& Kranzler, 1995), (ii) task value (e.g., Wang \& Eccles, 2013; Wigfield \& Eccles, 2000;), and (iii) effort expenditure (e.g., Dupeyrat \& Marine, 2005; Elliot, McGregor, \& Gable, 1999; Fenollar, Roman, \& Cuestas, 2007) on students' successful performance. Researchers have explored different strands of inquiries, amalgamating two or more concepts within one study to help explain and account for students' successful achievement.

\section{The Importance of Self-efficacy, Task Value, and Effort Expenditure on Academic Achievement}

\subsection{Self-efficacy}

In his social cognitive theory, Bandura $(1977,1986,1997)$ defined self-efficacy as beliefs in individuals' capabilities to perform specific courses of action, or accomplish certain outcomes (e.g., I believe I can understand the difference between countable and uncountable nouns in an English grammar lesson). Bandura (1986, 1997) stated that these self-efficacy beliefs influence students' behaviour in academic settings in several ways. First, they affect students' choice of behaviour. Students engage in and pursue activities in which they feel confident and competent, and they avoid those activities where they feel uncertain. Second, these efficacy beliefs help determine how much effort students will exert in their academic activities, how long they will persist when facing obstacles, and how resilient they will be when confronting adverse situations. Third, self-efficacy beliefs affect students' emotional reactions and thought patterns. Students with a low level of self-efficacy might perceive that academic activities are tougher than they really are, resulting in stress, depression, and a narrow view of how to solve an academic problem. Students with a high level of self-efficacy beliefs, in contrast, experience feelings of serenity and conviction when tackling difficult tasks and activities (Bandura, 1986, 1997).

In the last four decades since Bandura's (1977) seminal publication, substantial research studies have documented the influential effect of self-efficacy beliefs on students' achievement. For example, experimental studies in the 1980s (e.g., Schunk, 1982; Schunk \& Hanson, 1985), cross-sectional studies in the 1990s (e.g., Pajares \& Kranzler, 1995; Pajares \& Miller, 1994), and longitudinal studies in the 2010s (e.g., Breso et al., 2011; Phan, 2014) have provided evidence for and validated the positive association between self-efficacy beliefs and students' performance. This literature has detailed clear and consistent evidence that supports the unique contribution of self-efficacy (Bandura, 1986, 1997) on students' achievement outcomes; that is, students with high levels of self-efficacy beliefs are more likely to achieve at higher levels compared to those with low levels of self-efficacy beliefs.

\subsection{Task Value}

Task value is a significant and unique construct of the expectancy value theory (Wigfield \& Eccles, 1992, 2000). According to the theory (Wigfield \& Eccles, 2000), task value has been defined as students' perceptions of usefulness, importance, and interest in engaging in school activities. A student is more likely to accomplish a given task that he values, and avoid tasks that he does not value (Wigfield \& Eccles, 1992). The positive association between task value and academic achievement has been supported by many research studies using cross-sectional (e.g., Gonzalez \& Paoloni, 2015) and longitudinal data (e.g., Shim \& Ryan, 2005; Bong, 2001). The findings of these studies coincide with the theoretical tenet of expectancy value theory (Wigfield \& Eccles, 1992, 2000). The results have demonstrated that students who place higher value on their academic tasks are likely to succeed in learning and achieve better results. Students with a low level of task value, in contrast, might show less inclination toward achieving their academic tasks and, consequently, suffer in learning. These indications, significantly, highlight the importance of task value as an intervening variable to help strengthen students' academic performance.

\subsection{Effort Expenditure}

Effort expenditure, as a motivational factor, refers to the overall amount of effort expended in the learning process (Elliot et al., 1999; Zimmerman \& Risemberg, 1997). Effort expenditure is an important factor in explaining students' performance outcomes (Elliot et al., 1999; Fenollar et al., 2007). For example, students aiming to improve and complete their academic tasks successfully, are likely to expend more effort (Dupeyrat \& Marine, 2005; Elliot et al., 1999). Although it has not garnered the same level of extensive research as self-efficacy and task value, a large body of literature (e.g., Elliot et al., 1999; Fenollar et al., 2007; Phan, 2012) has demonstrated the positive relations between the effort students exert in the learning process and their academic achievement. The results of these studies have indicated that students exerting a certain amount of effort in their studies are more likely to achieve better results ultimately.

\section{The Influence of Active Learning Indicators on Students' Motivation and English Learning}

The overview of the literature presented above detailed the importance of the three motivational factors (i.e., self-efficacy, task value, and effort expenditure) on students' academic achievement. Because these motivational 
constructs play a potential role on students' successful achievement, the question then arises of which factors might contribute to their enhancement. A large body of empirical research has indicated that four indicators of active learning, namely (i) group work, (ii) elaborated feedback, (iii) situated learning, and (d) videos and pictures in classroom instruction, impact students' motivation and learning. The present study explores the use of these four indicators and their potential influences on the enhancement of the identified motivational constructs which, in turn, might account for increases in students' English achievement.

\subsection{Group Work}

Group work, as research has shown (Brown, 2001; Gass, 1997; Long \& Porter, 1985; Martin, 2005), is an ideal teaching strategy to foster students' motivation and English learning. Pertaining to students' motivation, the use of group work in classrooms can significantly influence Saudi students' various motivational factors (e.g., self-efficacy) in several ways. First, the use of group work is an effective way to maximise authentic peer interactions and create a mutually supportive environment (Long \& Porter, 1985). It is expected that mutual support and peer interaction may facilitate modelling, which is an important means to promote self-efficacy beliefs (Schunk \& Hanson, 1985; Johnson et al., 2014). Self-efficacy, according to Bandura (1997, 1986), is socially enhanced when students observe and compare performance with their peer models. Besides, interactions in group work might impact students' effort expenditure. It can be argued that when students work together in a group, they develop a group identity, exchange feedback, and encourage each other, which might stimulate them to expend more effort in their group work learning activities (Slavin, 1994).

Second, group work is an effective classroom teaching strategy for alleviating learners' excessive anxiety and developing their positive attitudes toward target language learning (Long \& Porter, 1985). Learners might feel less anxious, more confident, and freer to communicate and make mistakes during small group activities than during whole-class discussion (Long \& Porter, 1985). One of the key sources of self-efficacy beliefs is physiological states and emotional reactions (i.e., students' assessment of their levels of stress, mode states, anxiety, arousal, and fatigue) (Bandura, 1997). Therefore, the less sense of anxiety and stress is, the higher sense of self-efficacy beliefs will be (Bandura, 1997).

Third, students might find it comfortable, fun, and interesting to work in a safe and supportive learning environment such as group work (Brown, 2001), which therefore might have the potential to enhance intrinsic value. Overall, it is generally recommended by many research studies (e.g., Fredricks et al., 2004; Phan, 2011, 2013) that teaching practices and/or intervention program targeting to enhance students' motivation should involve group work activities.

With regard to students' English learning, a body of research (e.g., Ellis, 1999; Gass, 1997; Long, 1996; Long \& Porter, 1985) has revealed that group work, compared to whole-class instruction or a teacher-dominated classroom, can contribute to improving students' proficiency in English. For example, Long and Porter (1985) indicated that group work can provide students with increased times to practice English in classroom, which in turn improves their talk and communicative skills. Long and Porter asserted that, if classroom instruction is teacher-dominated, students seldom have genuine conversations in English. In a similar vein, various research studies have indicated that students working in small groups outperformed students working individually in various English skills such as writing (e.g., Storch, 2005), vocabulary (e.g., Kim, 2008), and grammar (e.g., Storch, 2007). For instance, Storch (2005) compared short texts written by students working in small groups with those of students working individually. The findings showed that students in small groups produced more grammatically accurate and linguistically complex texts than those who produced them individually.

\subsection{Elaborated Feedback}

The use of elaborated feedback is consistent with research findings (e.g., Black \& William, 1998; Hattie \& Timperly, 2007; Wang \& Wu, 2008) that highlight the importance of elaborated feedback on students' motivation and effective learning. Linnenbrink and Pintrich (2003) stated that providing students with focused, frequent, and task-specific feedback that outlines ways to improve can help enhance and maintain accurate self-efficacy judgements. Moreover, Wang and $\mathrm{Wu}$ (2008) found that students who were provided with elaborated feedback had greater self-efficacy beliefs than those who did not. Their study also reported that elaborated feedback significantly enhanced students' self-efficacy. Furthermore, elaborated feedback that highlights self-improvement, mastery, and achievement (e.g., you did well in the first task) can positively impact self-efficacy beliefs (Pintrich \& Schunk, 2002). In a similar vein, Haittie and Timperly (2007) argued that feedback involving guidance and strategies regarding how to improve can motivate students to invest more effort to achieve their learning goals. Apart from motivation, there is a large body of empirical research (e.g., Hattie, 1999; Hattie \& Gan, 2011; Hattie \& Timperly, 2007; Riviere, 1997) that discussed and detailed the effectiveness of elaborated feedback on students' achievement and effective learning. 


\subsection{Situated Learning}

Based on the situated learning perspective (Lave, 1988; Lave \& Wenger, 1991), effective learning takes place as long as learners are situated in a community of practice. In the present study, a Facebook group is used to facilitate a context of situated learning based on the community of practice. During the intervention program, students are involved in an online community of practice using Facebook group as the medium of communication with the aim of fostering, understanding, and improving their English learning in an authentic context.

The implementation of situated learning based on the Facebook community of practice can positively impact students' motivation and English learning. For example, Akbari, Naderi, Simons, and Pilot (2016) conducted an experimental study to examine the impacts of Facebook on English as a foreign language learners' motivation and learning. The findings indicated that, compared to the control group using the face-to-face method, the experimental group using Facebook as the medium of learning showed higher levels of engagement, motivation (i.e., interest, effort, and competence), and English learning outcomes. In addition, Kabilan, Ahmed, and Abidin (2010) investigated the role of Facebook as a meaningful and useful learning platform that could enhance students' English learning in Malaysia. Their study found that, in terms of affective factors, Facebook significantly improved students' motivation, confidence, and attitudes toward English learning. Furthermore, a number of research studies have reported the importance of Facebook as a medium of learning on students' various English skills such as writing (Razak, Saeed, \& Ahmad, 2013), reading (Haverback, 2009), vocabulary (Nikbakht \& Boshrabadi, 2015), grammar (Suthiwartnarueput \& Wasanasomsithi, 2012), and communicative skills (Omar, Embi, \& Yunus, 2012).

In a similar vein, the nature and characteristics of learning in the community of practice facilitated by a Facebook group have the potential to cultivate students' motivation. For example, Facebook has distinctive features (e.g., discussion board, instant message, chat, email, and the ability to upload pictures, videos, and links, and post comments) that provide students with opportunities to communicate, collaborate, and interact in an authentic context to improve their English learning (Omar et al., 2012). These learning opportunities can increase students' motivation and engagement as well as lead to more practical English learning experiences (Akbari et al., 2016; Dogoriti et al., 2014; Omar et al., 2012). In addition, Facebook enables students to share English learning materials (e.g., videos, audios, pictures, and links), discuss ideas and views, post topics and questions, and provide feedback on their group members' posts (Omar et al., 2012). Therefore, as students become members of the Facebook group, they have the opportunity to choose among a variety of learning materials and resources that are appropriate to their level and interest, which might stimulate their motivation to learn English.

In addition, Facebook creates a learning environment where there is freedom and autonomy for students to control the content and the direction of their learning without the constraints of time and place and the influence of teacher (Akbari, Pilot, \& Simons, 2015; Yunus \& Salehi, 2012). This autonomy can have a positive effect on students' motivation to learn English (Akbari et al., 2015). Also, Facebook offers an optimal environment for building a strong sense of community and belonging (Hurt et al., 2012). This strong sense of community is developed through the solidarity and unity of belonging to the same Facebook group because all members share one common learning purpose (i.e., improving their English; Yunus \& Salehi, 2012). A strong sense of community, according to researchers (e.g., Hurt et al., 2012; Martin, 2005), can promote students' motivation.

\subsection{Videos and Pictures in Classroom Instruction}

The integration of videos and pictures in classroom instruction is consistent with previous studies (e.g., Alkash \& Al-Dersi, 2013; Cakir, 2006; Susskind, 2008) that reported the importance of using visualisations (e.g., pictures and videos) by means of PowerPoint in the instructional setting to improve students' motivation and effective learning. For example, Susskind (2008) conducted a quasi-experimental study with university students to explore the impacts of accompanying lectures with PowerPoint presentations on students' self-efficacy, attitudes, and class-related behaviour (e.g., participation in class discussions, class attendance). The author reported that students had greater self-efficacy beliefs and displayed more positive attitudes toward the learning content when lectures were accompanied by PowerPoint presentations. The author further indicated that students believed lectures with PowerPoint presentations to be more organised, interesting, and enjoyable; in addition, they reported that such lectures motivated them to attend the class. In another study, Alkash and Al-Dersi (2013) investigated the usefulness of PowerPoint presentations (incorporated with visualisations) for English as foreign language students. The results of their study revealed that students were motivated and more engaged in the lessons when presented with PowerPoint. The results also indicated that PowerPoint made the class more interactive and enjoyable for students.

In a similar vein, Berk (2009) and Shah and Freedman (2003) discussed a number of benefits of using visualisations (e.g., pictures and videos) in teachers' instructions. Among these benefits, the authors noted that such visualisations 
generate interest in the class, improve attitudes toward content and learning, decrease anxiety and tension on complex topics, make learning fun, and attract and motivate students toward their learning. In a study that explored the usefulness of audio-visual tools in an English classroom in Saudi Arabia, Mathew and Alidmat (2013) showed that teaching and learning become uninteresting and monotonous when teachers rely only on textbooks as the main source of input. They further revealed that the use of audio-visual tools resulted in students perceiving the class as more interesting and effective. Similarly, Kabooha (2016) examined the perceptions of students and teachers toward the integration of video clips in English classes in Saudi Arabia. The results of the study indicated that students were more interested and motivated in learning English when teachers used videos in their instructions. The findings also indicated that teachers believed the use of videos increased students' participation and engagement in the classroom. In a similar vein, a number of recent research investigations have detailed the importance of the use of visualisations on students' various English skills such as reading (e.g., Lee, Lee, Liao, \& Wang, 2015), listening (e.g., Hamdan, 2015), speaking (Kurniawan, 2016), grammar (e.g., Moghadam \& Talafian, 2015), and vocabulary (e.g., Yuksel \& Tanriverdi, 2009).

\section{Research Focus}

The present study, experimental in nature, involves two-comparison groups (Experimental Group versus Control Group). The Experimental Group receives an eight-week intervention program including the four indicators of active learning (i.e., elaborated feedback, group work, situated learning, and videos and pictures in classroom instruction). The study spans three time points of data collection: Time 1 (before the intervention), Time 2 (in the middle of the intervention), and Time 3 (after the intervention). Students in both the Experimental Group and the Control Group complete the same measures of the motivational factors (i.e., self-efficacy, task value, and effort expenditure) and English achievement test repeatedly at each of the three time points (i.e., Time 1, Time 2, and Time 3). Methodologically, with the three waves of data collection, the study attempts to address the following overarching research aim:

To determine the extent to which the motivational factors and academic achievement change across Time 1, Time 2, and Time 3, as a result of the implementation of the educational intervention involving four indicators of active learning (i.e., elaborated feedback, group work, situated learning, and videos and pictures in classroom instruction).

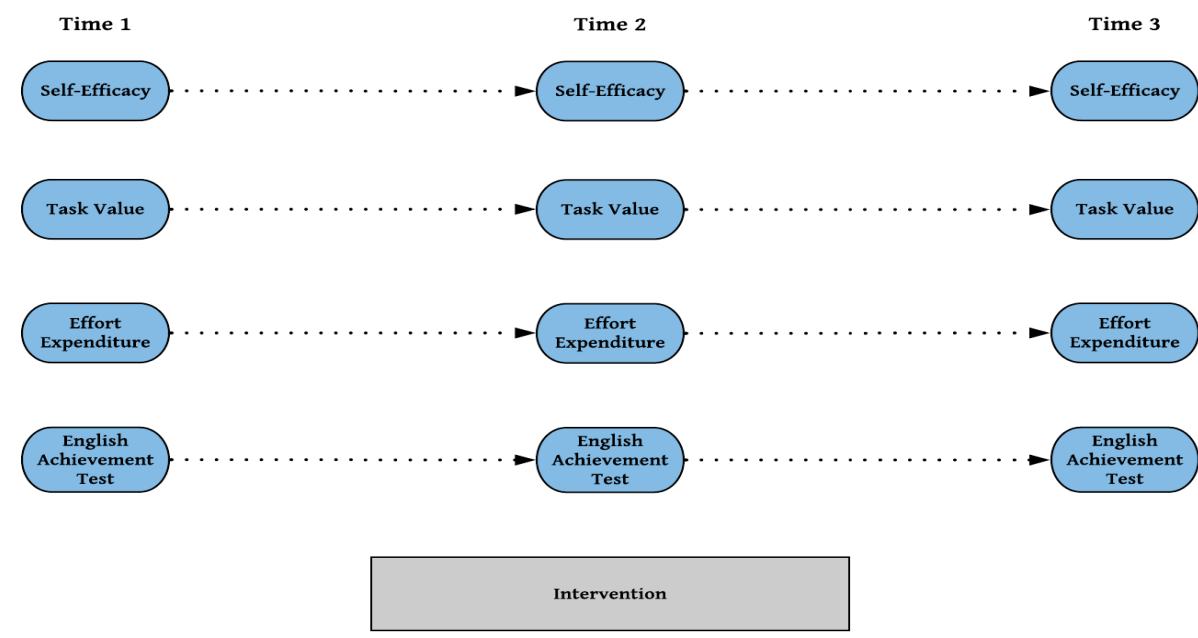

Figure 1. Hypothesized model depicting the influence of the intervention on changes in mean scores of self-efficacy, task value, effort expenditure, and English achievement test. Note: $\rightarrow$ = stability paths

In particular, there are four hypotheses for statistical testing concerning the impact of the intervention program on the motivational variables (i.e., self-efficacy, task value, and effort expenditure) and academic achievement:

$\mathbf{H}_{1}$ : Compared to students in the Control Group (those who did not participate in the intervention program), students in the Experimental Group would increase the mean scores of self-efficacy across Time 1, Time 2, and Time 3.

$\mathbf{H}_{2}$ : Compared to students in the Control Group, students in the Experimental Group would increase the mean scores of task value across Time 1, Time 2, and Time 3.

H3: Compared to students in the Control Group, students in the Experimental Group would increase the mean scores of effort expenditure across Time 1, Time 2, and Time 3. 
H4: Compared to students in the Control Group, students in the Experimental Group would increase the mean scores of academic achievement across Time 1, Time 2, and Time 3.

\section{Methodology}

Participants were 289 first-year university male ${ }^{1}$ Saudi Arabian students enrolled in an elementary-level English unit at a university in the northern part of Saudi Arabia. The original sample size comprised 299 students (150 in the Experimental Group, and 149 in the Control Group). However, only the students (145 in the Experimental Group, and 144 in the Control Group) who completed the three waves of data collection were included in the final analysis.

\subsection{The Intervention Program}

\subsubsection{Experimental Group}

The Experimental Group consisted of six classes (each class comprised 25 students, 150 students in total). The researcher and two assistant faculty members shared the teaching of the six classes in the Experimental Group. For example, in week one, the first faculty member taught classes A and B, the second faculty member taught classes $\mathrm{C}$ and D, and the researcher taught classes E and F. In week two, we swapped classes (e.g., the researcher taught classes $\mathrm{A}$ and $\mathrm{B}$, the first faculty member taught classes $\mathrm{C}$ and $\mathrm{D}$, and the second faculty member taught classes $\mathrm{E}$ and $\mathrm{F}$ ), and we continued this pattern throughout the 8-week intervention program. Before the commencement of this study, the researcher explained the purpose of the research and clearly described the intervention program to the two faculty members. The following paragraphs describe how the researcher and the two faculty members implemented the four indicators of active learning in the intervention program for the Experimental Group.

To implement group work and videos and pictures in classroom instruction, the researcher designed lesson plans, one for each lesson covered in the intervention program. These lesson plans served as a guide for the researcher and the two faculty members to implement group work and videos and pictures in classroom instruction. Each lesson plan included the materials of the lesson (e.g., videos, pictures). It also outlined the procedure of implementing group work and videos and pictures in classroom instruction.

For the use of videos and pictures in classroom instruction, each lesson plan required the instructors to use slides of PowerPoint (embedded where appropriate with pictures, videos, texts, tables, etc.) during the one-third of class time allocated for the teaching process (since the remaining two-thirds were devoted to group work activities). As outlined in the lesson plans, the instructors used PowerPoint slides with visualisations (e.g., videos and pictures), for instance, to introduce a new lesson (e.g., to introduce a speaking lesson about car accidents, the instructor showed students pictures and statistics about car accidents in Saudi Arabia), explain the main elements of the lesson (e.g., to explain a lesson in reading about the skimming technique, the instructor showed students a six-minute video on how to skim a text), and to provide a summary of the previous lesson.

With group work, students in each class were grouped into four-member, heterogeneous groups (i.e., with mixed levels of proficiency in English, as determined by their Time 1 score in English achievement test). In the first lesson, students of each group were instructed to sit and work together throughout the 8-week intervention program to ensure group stability (i.e., students were not allowed to swap groups). This long-term stable group provided students who were unfamiliar with group work to have sufficient time to develop group cohesion and overcome difficulties in working together. Based on the lesson plans, the implementation of group work in every lesson took the form of activities such as discussion of a particular topic (e.g., in a speaking activity, the instructor asked each group to discuss the main reasons for car accidents in Saudi Arabia), collaboration in doing activities (e.g., after introducing a lesson in grammar about the past tense, the instructor asked each group to work on an exercise related to the past tense), comparison of answers (e.g., after completing a group activity, the instructor asked each group to compare the answers with another group), and problem solving (e.g., after introducing a problem such as traffic jams, pollution, or car accidents, the instructor asked each group to write possible ways to solve the problem in a paragraph using simple present tense). Because of the flexibility to break each group of four into two pairs, students were instructed to work in pairs to complete some activities that required pair work such as role play (e.g., in a speaking activity about ordering food, the instructor asked one student to play the role of the waiter and the other to play the role of the customer in a restaurant). Finally, the instructor instructed students to use English only in group work activities, and Arabic was not permitted in the classroom.

Apart from videos and pictures and group work in classroom instruction, elaborated feedback was implemented in the intervention program in three main ways. First, students received elaborated feedback on three short tests (i.e.,

1 The participants were male because of gender segregation between men and women in Saudi educational institutions. 
prescribed as part of the assessment tasks and included in the final grade of the unit) that they had completed during the intervention program. Second, one of the university's unit requirements is for students to do at least one homework assignment every week to earn the $10 \%$ of the grade allocated for homework completion. Therefore, students were provided with consistent elaborated feedback on their homework, which addressed various language skills such as grammar, vocabulary, or writing. When providing elaborated feedback on these tests and homework, the instructors highlighted, for example, students' achievement (e.g., 'You did well in the first task'), self-improvement (e.g., 'This paragraph is better than your previous one. You started with a clear topic sentence followed by four supporting sentences.'), comments on strengths (e.g., 'I like the examples you provided in the paragraph. They helped support your argument.') and weaknesses (e.g., 'Your paragraph lacks coherence. Every paragraph should have one main idea stated in the topic sentence, and the following supporting sentences should clearly relate to that idea.'), and guidance on how to improve (e.g., 'use auxiliary verbs [e.g., is, are, am] in your sentences. Please see handout number three, which includes explanations and examples on how to use these auxiliary verbs.'). Third, the instructors used checklist notes to identify popular mistakes among students in the activities of the classroom (e.g., wrong use of helping verbs in speaking and writing, wrong utterance in particular words), tests, and homework. The instructors then provided elaborated feedback on these common issues and posted the feedback on each class's Facebook group.

Finally, to implement situated learning, a Facebook group was used in the intervention program to facilitate a context of situated learning based on the notion of community of practice (Lave, 1988; Lave \& Wenger, 1991). The instructors created a Facebook group for each of the six classes of the Experimental Group. Students in each class were instructed to interact and participate in their Facebook group community at least three times a week. They were instructed to work together, help each other, and share materials of English learning such as videos, pictures, links, and audios. They were also required to post questions, comments, and ideas on different topics, and participate in any other suitable activities that could help them to improve their learning of English (e.g., see a screenshot of students' post in the Facebook group in Figure 2). The instructors posted announcements, discussion topics, feedback on students' work, and relevant information on English learning. Moreover, they supervised the groups to ensure that students communicated with each other in online discussions.
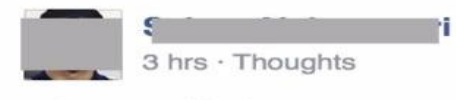

salam my frinds

I find this vido in youtub. it about every day conversations. it have subtitle therefore you understand easy.

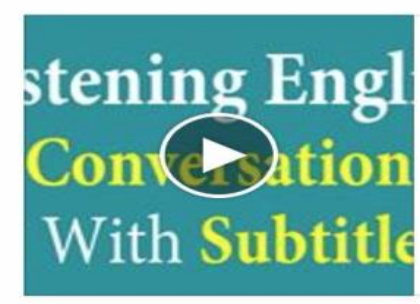

\section{Listening English Conversation With} Subtitle - Learn English Listening

Listening English Conversation With Subtitle - Learn English Listening. Thanks for watching! Please share and like if you enjoyed the video :) thanks so ...

YOUTUBE.COM

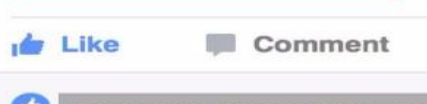

Share

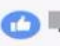

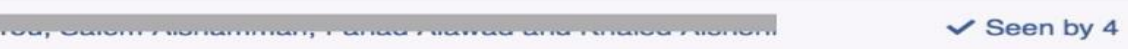

it is usefol video. thanks salem

Unlike - Reply - 3 - 16 mins

thank you for the good vidio salem. my problem is the listening and $i$ think this video is little fast for me Unlike - Reply - $2 \cdot 2 \mathrm{hrs}$

fi good salem. the good thing in this video it has subtitle. it is good while you listen you see the translation. it's the best conversation ही ही? tnx a lot 6

Like - Reply - 2 hrs

Figure 2. A screenshot of students' posts in the Facebook group 


\subsubsection{Control Group}

Similar to the Experimental Group, the Control Group consisted of six classes (i.e., each class comprised 25 students except one class, which had 24 students, 149 students in total). Students in the Control Group were not exposed to the four active learning indicators. They used the same textbook, completed the same assessment tasks (e.g., homework and quizzes), attended the same number of classes, and were taught the same topics as the Experimental Group. They had their normal lessons taught by their instructors (three instructors, none of whom was involved in the Experimental Group) using the traditional lecture approach. The students, in this instance, were taught mainly through listening to the instructor's explanations and taking notes, answering the instructor's questions, whole class discussion, and reading aloud.

\subsection{Measures}

All measures used in this study were delivered in Arabic, since most of the participants had minimal understanding of English and Arabic was their first language. The items of the measures (except for the measure assessing English achievement) were translated into Arabic using independent back-translation. During this process, an English-qualified native Arabic speaker translated the items into Arabic before a bilingual native English speaker who was not part of the research team translated them back to English. To ensure that the translation was accurate and equivalent, another native English speaker, unfamiliar with the study, reviewed the two English versions to ensure their equivalence in meaning.

With the exception of the measure of English achievement, existing measures with proven validity and reliability were used in this study. Students were given, at each time point, a folder that contained measures to assess their motivational factors (i.e., self-efficacy, task value, and effort expenditure) and English achievement. Students responded to each measure item using a seven-point Likert-type scale ranging from 1 (definitely disagree) to 7 (definitely agree), except for the questions measuring students' English achievement. English was the target area for rating.

Self-efficacy: Three items from the self-efficacy subscale of the Motivated Strategies for Learning Questionnaire [MSLQ] (Pintrich, Smith, Garcia, \& Mckeachie, 1993) were used to assess students' self-efficacy. A sample item includes "I believe I will receive an excellent grade in this unit, English".

Task value: Four items from the task value subscale of the MSLQ (Pintrich et al., 1993) were used to measure students' task value. A sample item includes "I am very interested in the content area of this unit, English".

Effort expenditure: Effort expenditure was measured by three items adapted from Elliot et al. (1999) and Pintrich et al. (1993). A sample item for this scale is "I put a lot of effort into preparing for the exam of this unit, English".

Academic achievement: Students' English achievement was measured using a fifty-minute test designed by the researcher and reviewed by the two faculty members. The test was based on the prescribed unit textbook, and it was divided into five parts, as follows: Grammar (20\%), Vocabulary (20\%), Reading comprehension (20\%), Listening (20\%), and Writing (20\%).

\section{Data Analysis}

A 2 (Group: Experimental Group, Control Group) x 3 (Time: Time 1, Time 2, Time 3) ANOVA was conducted to test differences between the Experimental Group versus the Control Group to determine if the intervention made impacts on students' motivational constructs (i.e., self-efficacy, task value, and effort expenditure) and academic achievement across Time 1, Time 2, and Time 3. The independent variables are the Experimental Group and the Control Group. The dependent variables are the mean scores for self-efficacy, task value, effort expenditure, and academic achievement across Time 1, Time 2, and Time 3. The first independent variable (i.e., Group) was a between-subjects factor, and the second independent variable (i.e., Time) was a within-subjects repeated measures factor. As discussed previously, the data at Time 1 were collected before the intervention, the data at Time 2 were collected in the middle of the intervention, and the data at Time 3 were collected after the intervention. Given that the data at Time 1 were collected at baseline, it is expected that no difference will be found between the two groups prior to the implementation of the intervention. Means and standard deviations for the dependent variables are presented in Table 1. The results for 2 (Group: Experimental Group, Control Group) x 3 (Time: Time 1, Time 2, Time 3) ANOVA on the dependent variables are displayed in Table 2. In order to affirm differences between the Experimental Group and the Control Group at each time point, follow up $t$-tests were computed (Table 3). 
Table 1. Means and standard deviations on self-efficacy, task value, effort expenditure, and academic achievement for the Experimental Group and the Control Group across Time 1, Time 2, and Time 3

\begin{tabular}{ccccccc}
\hline & \multicolumn{3}{c}{ Control Group $(n=144)$} & \multicolumn{2}{c}{ Experimental Group $(n=145)$} \\
\hline & Time 1 & Time 2 & Time 3 & Time 1 & Time 2 & Time 3 \\
\hline & Mean (SD) & Mean (SD) & Mean (SD) & Mean (SD) & Mean (SD) & Mean (SD) \\
\hline Self-Efficacy & $4.52(1.73)$ & $4.33(1.65)$ & $4.11(1.70)$ & $4.54(1.60)$ & $4.91(1.41)$ & $5.52(1.18)$ \\
Task Value & $4.76(1.60)$ & $4.53(1.54)$ & $4.47(1.55)$ & $4.94(1.62)$ & $4.98(1.63)$ & $5.20(1.46)$ \\
& & & & & \\
Effort Expenditure & $4.38(1.80)$ & $4.67(1.59)$ & $5.04(1.50)$ & $4.57(1.77)$ & $5.14(1.53)$ & $5.61(1.47)$ \\
Academic & 56.88 & 59.13 & 61.01 & 59.28 & 67.08 & 74.61 \\
Achievement & $(22.16)$ & $(22.00)$ & $(22.01)$ & $(19.73)$ & $(17.80)$ & $(16.14)$ \\
\hline
\end{tabular}

Table 2. The results of a 2 (Group: Experimental Group, Control Group) x 3 (Time: Time 1, Time 2, Time 3) ANOVA on self-efficacy, task value, effort expenditure, and academic achievement

\begin{tabular}{llll}
\hline & $\boldsymbol{F}$ & $\boldsymbol{p}$ & $\eta^{2}$ \\
\hline Self-Efficacy & 23.01 & $* * *$ & 0.07 \\
Time & 139.06 & $* * *$ & 0.33 \\
Group x Time & 14.96 & $* * *$ & 0.05 \\
Group & & & \\
\hline Task Value & 0.17 & $\mathrm{~ns}$ & 0.00 \\
Time & 34.03 & $* * *$ & 0.11 \\
Group x Time & 6.49 & $* *$ & 0.02 \\
Group & 128.71 & $* * *$ & 0.31 \\
\hline Effort Expenditure & 6.04 & $* *$ & 0.02 \\
Time & 5.39 & $* *$ & 0.02 \\
Group x Time & & & \\
Group & 915.13 & $* * *$ & 0.76 \\
\hline Academic Achievement & 302.40 & $* * *$ & 0.51 \\
Time & 11.60 & $* * *$ & 0.04 \\
Group x Time & & & \\
Group & & &
\end{tabular}

Note: $* \mathrm{p}<.05, * * \mathrm{p}<.01, * * * \mathrm{p}<.001$ 
Table 3. A comparison between the Experimental Group and the Control Group on self-efficacy, task value, effort expenditure, and academic achievement across Time 1, Time 2, and Time 3

\begin{tabular}{llllll}
\hline & $\begin{array}{l}\text { Experimental } \\
\text { Group }\end{array}$ & $\begin{array}{l}\text { Control } \\
\text { Group }\end{array}$ & & & \\
\hline M (SD) & M (SD) & $\boldsymbol{t}$-value & $\boldsymbol{p}$ & Cohen's $\boldsymbol{d}$ \\
\hline Self-Efficacy & & & & \\
Time 1 & $4.54(1.60)$ & $4.52(1.73)$ & 0.11 & $\mathrm{~ns}$ & - \\
Time 2 & $4.91(1.41)$ & $4.33(1.65)$ & 3.21 & $* * *$ & 0.38 \\
Time 3 & $5.52(1.18)$ & $4.11(1.70)$ & 8.21 & $* * *$ & 0.97 \\
\hline Task Value & & & & & \\
Time 1 & $4.94(1.62)$ & $4.76(1.60)$ & 0.96 & $\mathrm{~ns}$ & - \\
Time 2 & $4.98(1.63)$ & $4.53(1.54)$ & 2.42 & $*$ & 0.29 \\
Time 3 & $5.20(1.46)$ & $4.47(1.55)$ & 4.14 & $* * *$ & 0.49 \\
\hline Effort Expenditure & & & & & \\
Time 1 & $4.57(1.77)$ & $4.38(1.80)$ & 0.93 & $\mathrm{~ns}$ & - \\
Time 2 & $5.14(1.53)$ & $4.67(1.59)$ & 2.56 & $* *$ & 0.30 \\
Time 3 & $5.61(1.47)$ & $5.04(1.50)$ & 3.24 & $* * *$ & 0.38 \\
\hline Academic Achievement & & & & & \\
Time 1 & $59.28(19.73)$ & $56.88(22.16)$ & 0.98 & $\mathrm{~ns}$ & - \\
Time 2 & $67.08(17.80)$ & $59.13(22.00)$ & 3.38 & $* * *$ & 0.40 \\
Time 3 & $74.61(16.14)$ & $61.01(22.01)$ & 5.99 & $* * *$ & 0.71 \\
\hline
\end{tabular}

Note: Cohen (1988) classified effect sizes as no effect $(d=0.0-0.2)$, small effect $(d=0.2-0.49)$, medium effect $(d$ $=0.5-0.79)$, and large effect $(d=\geq 0.8){ }^{*} \mathrm{p}<.05, * * \mathrm{p}<.01, * * * \mathrm{p}<.001$ by independent $t$-test.

6.1 Self-efficacy

A 2 (Group: Experimental Group, Control Group) x 3 (Time: Time 1, Time 2, Time 3) ANOVA performed on the mean scores of self-efficacy indicated a significant effect on Time, $F(1,287)=23.01, M S E=0.50, p<.001, \eta^{2}=0.07$, suggesting that there were differential mean scores between the two groups across the three time points. There was a significant effect on Group x Time, $F(1,287)=139.06, M S E=0.50, p<.001, \eta^{2}=0.33$, suggesting that the difference between the two groups was more pronounced on Time 2 and Time 3 rather than Time 1 (Figure 3). In addition, a significant effect was found on Group, $F(1,287)=14.96, M S E=6.52, p<.001, \eta^{2}=0.05$, suggesting that the Experiment Group outperformed the Control Group on Time 2 and Time 3. As illustrated in Figure 3, there was a difference between the Experimental Group and the Control Group on the mean scores on Time 2 and Time 3, but not Time 1. Follow-up $t$-tests confirmed that the two groups did not differ on Time $1, t(287)=0.11, S E=0.20, p=0.91$. However, the two groups differed on Time $2, t(287)=3.21, S E=0.18, p<.001$, Cohen's $d=0.38$ (a small effect), and Time 3, $t(287)=8.21, S E=0.17, p<.001$, Cohen's $d=0.97$ (a large effect), as illustrated in Table 3. Clearly, effect size (Cohen's $d$ ) revealed that the difference between the two groups was greater on Time 3 as compared to Time 2 (see Figure 3). Of particular interest is that the Control Group gradually decreased in the mean scores of self-efficacy from Time 1 to Time 3. 


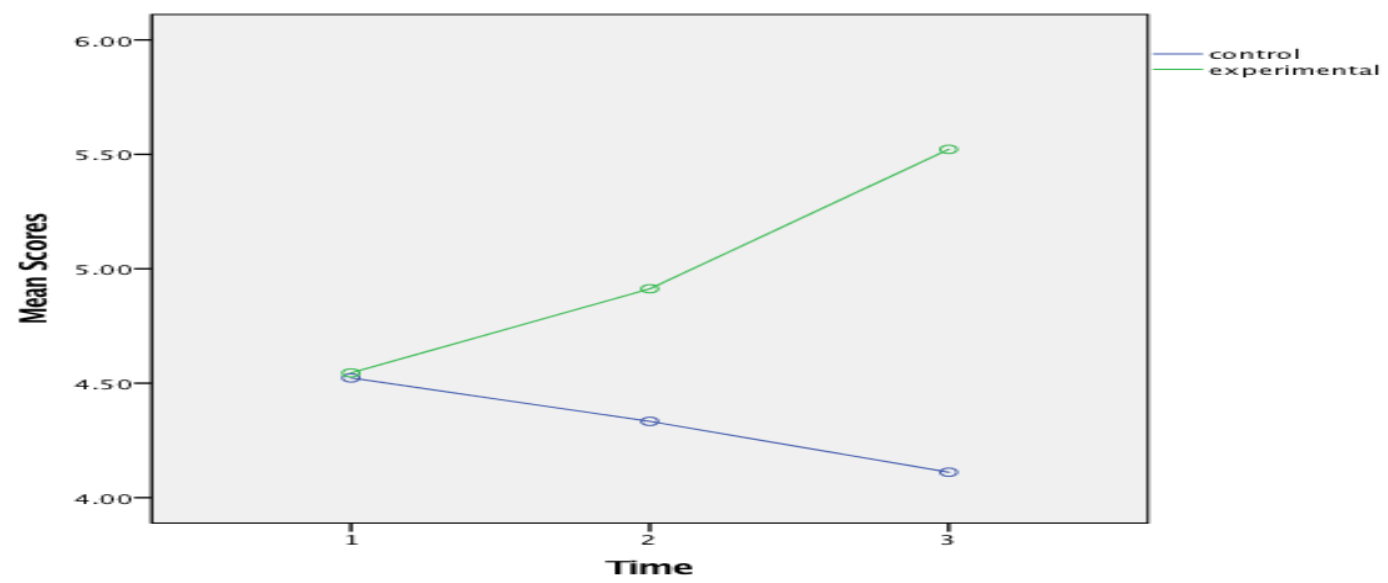

Figure 3. The mean scores of self-efficacy between the Experimental Group and the Control Group across Time 1, Time 2 and Time 3

\subsection{Task Value}

A 2 (Group: Experimental Group, Control Group) x 3 (Time: Time 1, Time 2, Time 3) ANOVA performed on the mean scores of task value indicated a non-significant effect on Time, $F(1,287)=0.17, M S E=0.32, p=0.69, \eta^{2}=$ 0.00 . However, there was a significant effect on Group x Time, $F(1,287)=34.03, M S E=0.32, p<.001, \eta^{2}=0.11$, and a significant effect on Group, $F(1,287)=6.49, M S E=6.92, p=0.01, \eta^{2}=0.02$. As indicated in Figure 4, there was a difference between the Experimental Group and the Control Group on the mean scores on Time 2 and Time 3, but only a marginal difference on Time 1. Follow-up $t$-tests indicated that the two groups did not differ on Time $1, t(287)=0.96$, $S E=0.19, p=0.34$. However, the two groups differed on Time 2, $t(287)=2.42, S E=0.19, p=0.02$, Cohen's $d=0.29$ (a small effect), and Time 3, $t(287)=4.14, S E=0.18, p<.001$, Cohen's $d=0.49$ (a small effect). Once again, the Control Group showed a slight decrease in the mean scores of task value from Time 1 to Time 3.

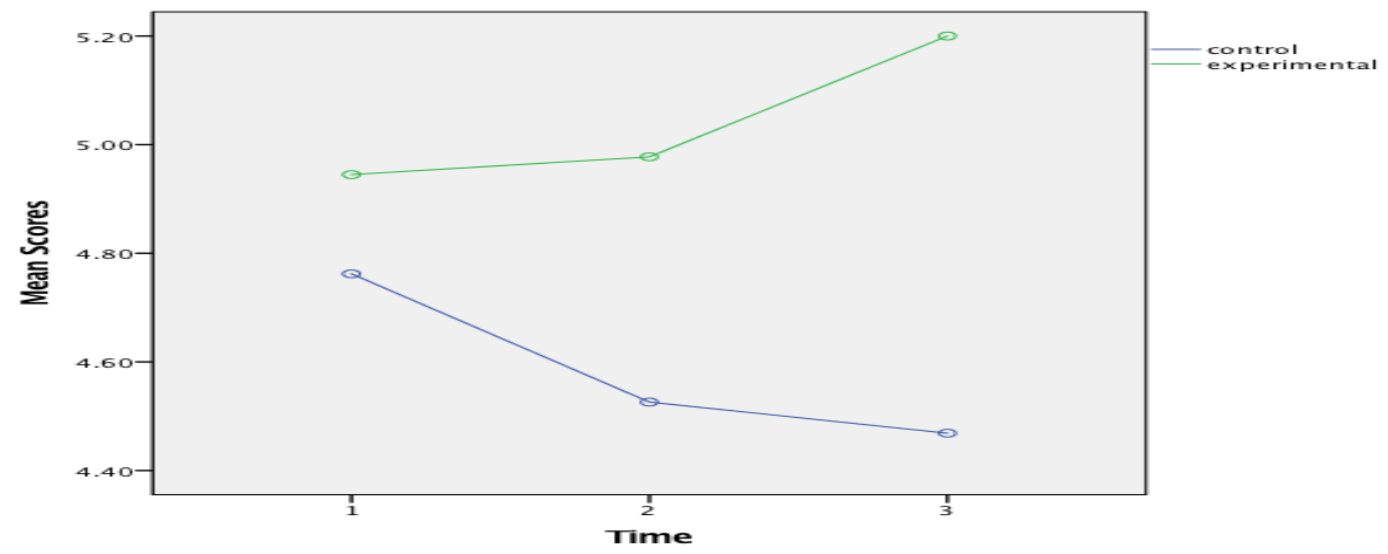

Figure 4. The mean scores of task value between the Experimental Group and the Control Group across Time 1, Time 2 and Time 3

\subsection{Effort Expenditure}

A 2 (Group: Experimental Group, Control Group) x 3 (Time: Time 1, Time 2, Time 3) ANOVA was performed on the mean scores of effort expenditure. There was a significant effect on Time, $F(1,287)=128.71, M S E=0.82, p<.001$, $\eta^{2}=0.31$, a significant effect on Group x Time, $F(1,287)=6.04, M S E=0.82, p=0.02, \eta^{2}=0.02$, and a significant effect on Group, $F(1,287)=5.39, M S E=6.78, p=0.02, \eta^{2}=0.02$. As can be seen in Figure 5, contrary to the mean scores of self-efficacy and task value, both the Experimental Group and the Control Group showed an increase in the mean scores of effort expenditure across the three time points. To better understand the difference between the two groups over time, follow up $t$-tests were run and indicated that the two groups did not differ at Time $1, t(287)=0.93$, $S E=0.21, p=0.35$. However, there was a significant difference between the two groups at Time 2, $t(287)=2.56, S E=$ $0.18, p=0.01$, Cohen's $d=0.30$ (a small effect), and at Time 3, $t(287)=3.24, S E=0.17, p<.001$, Cohen's $d=0.38$ 
(a small effect). Similar to task value, the effect size (Cohen's $d$ ) was small at both Time 2 and Time 3 (see Table 3).

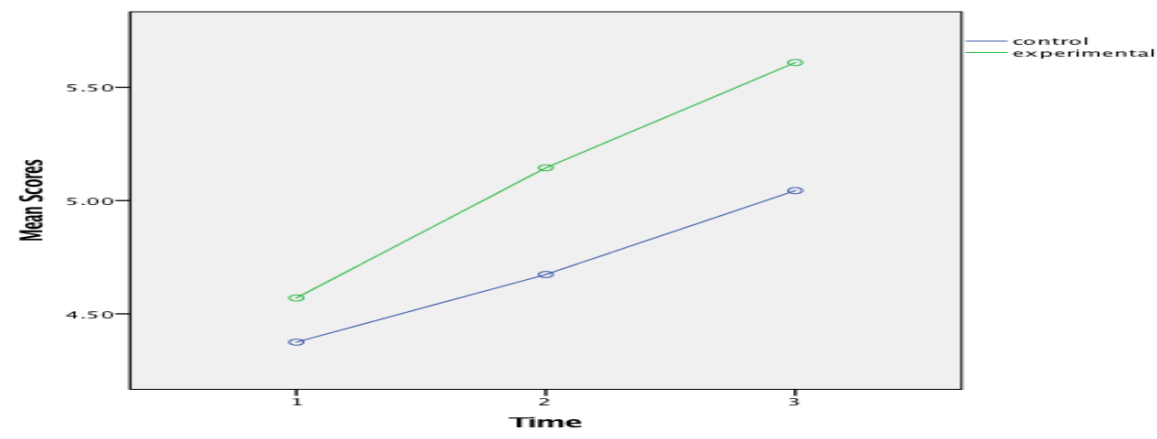

Figure 5. The mean scores of effort expenditure between the Experimental Group and the Control Group across Time 1 , Time 2 and Time 3

\subsection{Academic Achievement}

A 2 (Group: Experimental Group, Control Group) x 3 (Time: Time 1, Time 2, Time 3) ANOVA was conducted on the mean scores of academic achievement. The analysis revealed a significant effect of Time, $F(1,287)=915.13, M S E=$ $14.96, p<.001, \eta^{2}=0.76$, of Group x Time, $F(1,287)=302.40, M S E=14.96, p<.001, \eta^{2}=0.51$, and of Group, $F(1$, $287)=11.60, M S E=1191.37, p<.001, \eta^{2}=0.04$. Figure 6 shows the mean scores of academic achievement between the Experimental Group and the Control Group, where both groups increased gradually across the three time points. To better understand the difference between the two groups over time, follow up $t$-tests were run and indicated that there was a non-significant difference between the two groups at Time $1, t(287)=0.98, S E=2.47, p=0.33$. However, there was a significant difference between the two groups at Time 2, $t(287)=3.38, S E=2.35, p<.001$, Cohen's $d=0.40$ (a small effect), and at Time 3, $t(287)=5.99, S E=2.27, p<.001$, Cohen's $d=0.71$ (a medium effect).

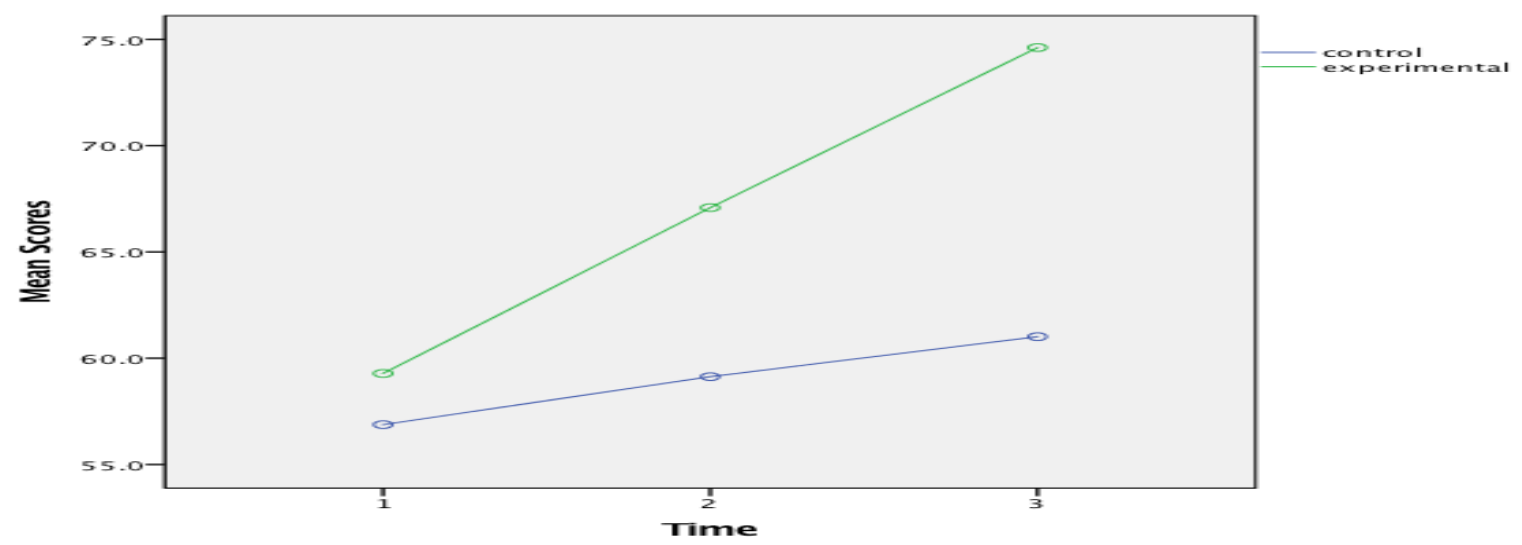

Figure 6. The mean scores of academic achievement between the Experimental Group and the Control Group across Time 1, Time 2 and Time 3

\section{Discussion}

The present experimental study investigated the impact of an eight-week intervention program involving four indicators of active learning (i.e., elaborated feedback, group work, situated learning, and videos and pictures in classroom instruction) on Saudi students' motivational constructs (i.e., self-efficacy, task value, and effort expenditure), and academic achievement in English. The major finding of the present study is that the Experimental Group, exposed to the intervention program, scored significantly higher than the Control Group on the motivational constructs and English achievement. Specifically, the results of 2 (Group: Experimental Group, Control Group) x 3 (Time: Time 1, Time 2, Time 3) ANOVA and follow-up $t$-tests showed that the intervention had small effects on all the variables at Time 2 (i.e., effect size was $d=0.38$ for self-efficacy, $d=0.29$ for task value, $d=0.30$ for effort expenditure, and $d=0.40$ for academic achievement). However, at Time 3 , the intervention had small effects on task value $(d=0.49)$ and effort expenditure $(d=0.38)$, a moderate effect on academic achievement $(d=0.71)$, and a large effect on self-efficacy $(d=$ 0.97). Interestingly, the findings also showed that the Control Group, as compared to increases in the Experimental Group, showed overall declines in the variables (except in effort expenditure and academic achievement) from Time 1 to Time 3. These findings and the possible explanations for them are discussed below. 
The results of the current study are in line with previous experimental/quasi-experimental studies that have documented the utility of various intervention programs in accounting for changes in students' motivation and academic achievement (e.g., Bandura \& Schunk, 1981; Breso et al., 2011; Hulleman et al., 2010; Martin, 2005, 2008; Schunk, 1982). These studies have reported the effectiveness of intervention programs lasting from a few days (e.g., Hulleman et al., 2010; Martin, 2005), a few weeks (e.g., Martin, 2008), to a few months (e.g., Breso et al., 2011) on students' motivation and performance. In addition, the findings of this study support the results of previous experimental/quasi-experimental studies and theoretical views that detailed the positive impacts of group work (e.g., Bejarano, 1987; Long, 1996; Long \& Porter, 1985), Facebook group (e.g., Akbari et al., 2016; Omar et al., 2012; Kabilan et al., 2010), elaborated feedback (e.g., Black \& William, 1998; Hattie \& Timperly, 2007; Wang \& Wu, 2008), and the use of videos and pictures in classroom instruction (e.g., Cakir, 2006; Lee \& Lee, 2015; Susskind, 2008) on students' motivation and academic achievement.

The results of the current study, as noted earlier, showed that the effects of the intervention were greater at Time 3 (after the intervention) than at Time 2 (in the middle of the intervention) on the dependent variables, except on task value and effort expenditure. These findings might suggest that, the longer the Experimental Group were exposed to the four active learning indicators, the greater their motivation and achievement were. At the same time, given that the intervention had significant effects on the variables at Time 2 (i.e., on the fourth week of the intervention), a practical implication is that interventions may not need to be long-lasting to be effective (Martin, 2005).

In a similar vein, the findings that the Experimental Group made smaller gains on task value and effort expenditure than on the other variables can be explained by the following. An examination of the mean scores for task value at Time 1 (before the intervention) shows that both groups reported higher levels of task value than the other variables (i.e., 4.94 and 4.76 for the Experimental Group and the Control Group, respectively). It is unsurprising that Saudi students place great value on English learning as English, for example, is a prerequisite for getting a job in the private sector, communicating with foreign expatriates in the country, gaining admission for further studies (e.g., master degree), or making online purchases. Hence, it is understandable that the two groups would place higher values on English learning, with little room for the Experimental Group to improve. Similarly, for effort expenditure, it is worth noting that both the Experimental Group and the Control Group showed increases for the mean scores of effort expenditure across the three time points. This increase in the mean scores of effort expenditure for both groups is expected, given that the sample of this study were university students who realized the importance of exerting effort to pass the unit. Therefore, as both groups increased their effort across the three time points, it is also understandable that the Experimental Group made smaller gains in this variable than in other variables.

Interestingly, this study's findings showed that, while the Experimental Group demonstrated increases, the Control Group exhibited general declines in the variables (except in effort expenditure and academic achievement) across the three time points. A possible explanation might be that students in the Control Group held higher perceptions of motivation before they started learning the English unit. However, as they progressed in their study of this English unit, they could have been affected by factors such as the teaching methods (e.g., teacher-centered approach and rote learning), and the materials (e.g., the lack of diverse teaching resources), which might have contributed to the declines in their motivation. This general decline in the levels of motivation have been well documented in the literature (e.g., Eccles, Wigfield, \& Schiefele, 1998; Martin et al., 2015; Pintrich \& Schunk, 2002). In the context of foreign language learning, researchers (e.g., Gardner, Masgoret, Tennant, \& Mihic, 2004; Koizumi \& Matsuo, 1993; Tachibana, Matsuoka, \& Zhong, 1996) have documented declines in students' motivation after a certain period of the actual study of foreign languages. For example, Gardner et al. (2004) recruited 197 university students studying a foreign language and indicated that the students showed decreases in their motivation across six occasions over an academic year of studying the language. In a similar vein, in the Saudi Arabian setting, Almaiman (2005) found that the motivation of 301 English learners declined after one academic year of experiencing English learning. The decline in motivation of the Control Group might support the importance of the four active learning indicators implemented in the intervention program in maintaining and increasing the levels of motivation of the Experimental Group.

\section{Contributions of the Study}

The results of the present study have made several major theoretical and practical contributions. Theoretically, one important implication arising from this research investigation is the identification of salient active learning strategies that could function to influence students' motivational beliefs and English achievement. Significantly, acknowledging previous research development, I have integrated four different but comparable indicators of active learning in one conceptual model, which I postulated to exert positive influences on the various motivational 
constructs and English achievement (i.e., elaborated feedback, group work, situated learning, and videos and pictures use in classroom instruction). Evidence obtained from quantitative analyses, as reported and discussed, indicates the importance of the four indicators of active learning implemented.

Educationally, of course, the current study has provided some pedagogical practices for implementation. Policymakers, teachers, and trainers of teachers can benefit from these results, which demonstrated the importance of the four active learning indicators on students' motivation and achievement outcomes. It is important to encourage and train English teachers in Saudi Arabia on how to use the four indicators of active learning. For example, training workshops/sessions should be offered to help English teachers to maximise the potential of the four active learning indicators to improve their students' motivation and English learning. Teachers should be trained to provide consistent, timely, and constructive elaborated feedback on their students' homework, quizzes, and exams. They should learn that this elaborated feedback must detail guidance and hints on how to improve rather than only providing summative grades or only notifying students whether their answers were right or wrong. In addition, they need to be aware that the feedback should point out students' strength and weaknesses, and it should be simple, clear, and compatible with students' previous performance.

When implementing group work in their classes, English teachers need to be trained, for example, that they should choose appropriate groups sizes with mixed levels of abilities (i.e., heterogeneous groups). In addition, as mentioned previously, these groups should be long-term (i.e., the members of each group should be stable throughout the semester) to allow students to develop group cohesion and overcome difficulties in working together. Teachers also need to encourage and instruct students to use English only during group work activities to increase their language practice.

Similarly, it is important to encourage English teachers to engage their students in online communities of practice using a Facebook group as the medium of communication to facilitate their learning in an authentic context. Teachers should create a Facebook group for each of their classes and encourage students to communicate, discuss, collaborate, and exchange learning materials and resources to improve their learning outside the classroom setting. Teachers also need, for example, to encourage a high level of participation, reply to students' enquiries and questions, and post announcements, discussion topics, and feedback on their students' common mistakes.

In addition, to promote their students' motivation and learning, teachers of English in Saudi Arabia need to accompany their instructions with learning visualisations (i.e., videos and pictures). The use of videos and pictures in classroom instruction generate interest and enjoyment in the classroom, attract students' attention, and offer students with authentic experiences of learning to understand difficult tasks, thus facilitating their learning and motivation. It is recommended, therefore, that educational authorities in Saudi Arabia offer continuous support to help English teachers use these ICT tools. This support includes, for example, providing schools and universities with classroom ICT resources (e.g., computers, data show projectors, multimedia devices, and software), training teachers especially those who lack confidence in using ICT - on how to use these technical resources, providing timely maintenance to these technical resources, and training teachers on how to search and choose various videos and pictures from the web according to their students' learning needs and levels.

\section{Caveats and Future Directions}

Aside from theoretical and practical contribution, it is important to note that the current study also experienced and has produced a number of caveats that are worthy for inclusion. In this section, I want to focus in detail on two major issues for development. Firstly, the experimental design utilized was limited. In an ideal situation, as Phan and Ngu (2017) explained, researchers would consider the use of the Solomon Four-Group experimental design. This complex experimental design would permit the factoring of different extraneous influences - for example, referring to this study, it is possible that exposure to a particular instructor made a difference in the way to which the participants responded. In other words, a group's mean score for a motivational variable (e.g., self-efficacy) could have improved, consequently as a result of the attitude and/or personality of the instructor himself, and not necessarily because of the intervention.

My two-group design (i.e., Experimental Group versus Control Group), in this case because of a limited sample size, was restricted and simplistic, in nature. Such a limited design (i.e., combining the four indicators as one experimental intervention) did not enable me to determine the comparative influences of the four indicators (e.g., the effectiveness of elaborated feedback versus the effectiveness of group work). Ideally, and I recommend researchers to consider, it would be more appropriate to implement a multi-group experimental design, as shown: 
i.EG $\mathrm{EG}_{1} \mathrm{O}_{1} \rightarrow \mathrm{X}_{1} \rightarrow \mathrm{O}_{3}$, where $\mathrm{EG}_{1}=$ Experimental Group $1, \mathrm{O}_{1}=$ collection of data at Time $1, \mathrm{O}_{3}=$ collection of data at Time 3 , and $\mathrm{X}_{1}=$ intervention at Time 2, which involves the use of group work.

ii.EG $\mathrm{EG}_{2} \mathrm{O}_{1} \rightarrow \mathrm{X}_{2} \rightarrow \mathrm{O}_{3}$, where $\mathrm{EG}_{2}=$ Experimental Group 2, $\mathrm{O}_{1}=$ collection of data at Time $1, \mathrm{O}_{3}=$ collection of data at Time 3, and $\mathrm{X}_{2}=$ intervention at Time 2, which involves the use of elaborated feedback.

iii.EG $\mathrm{EG}_{3} \mathrm{O}_{1} \rightarrow \mathrm{X}_{3} \rightarrow \mathrm{O}_{3}$, where $\mathrm{EG}_{3}=$ Experimental Group 3, $\mathrm{O}_{1}=$ collection of data at Time $1, \mathrm{O}_{3}=$ collection of data at Time 3, and $\mathrm{X}_{3}=$ intervention at Time 2, which involves the use of situated learning.

iv.EG $\mathrm{E}_{4} \mathrm{O}_{1} \rightarrow \mathrm{X}_{4} \rightarrow \mathrm{O}_{3}$, where $\mathrm{EG}_{4}=$ Experimental Group 4, $\mathrm{O}_{1}=$ collection of data at Time $1, \mathrm{O}_{3}=$ collection of data at Time 3, and $\mathrm{X}_{4}=$ intervention at Time 2, which involves the use of videos and pictures in classroom instruction.

v.CG: $\mathrm{O}_{1} \rightarrow \mathrm{O}_{3}$, where $\mathrm{CG}=$ Control Group, $\mathrm{O}_{1}=$ collection of data at Time 1 , and $\mathrm{O}_{3}=$ collection of data at Time 3.

The above description shows a five-group comparison between a control group (CG) and four experimental groups (i.e., $\mathrm{EG}_{1}-\mathrm{EG}_{4}$ ). This experimental design, of course, would require a larger sample size, even so especially if we wish to consider using complex inferential statistics. However, a number of contextual situations limited me from undertaking this proposed experimental design - namely: (i) the limited sample size, (ii) the limited time available to conduct this study, and (iii) the lack of an adequate number of academic staff to help me teach the four groups. Future research should determine, which of the four active learning indicators has the largest impacts on students' motivation and English learning.

Secondly, the sociocultural context of Saudi Arabia recognizes a number of cultural attributes, customary practices, and specific values. One clear indication of this is the segregation of society based on gender. Because I am a Saudi man and the institution and participants involved are all men, it is not possible in this case for us to consider the notion of generalization of results to the wider population. The results of the current study, of course, have advanced our understanding of motivational theories and students' academic learning for the subject English. My contributions, in totality, have added more fruitful information to the empirical literature. However, having said this, I am also mindful that the study did not provide nor reflect a balanced conceptualization in terms of genders. To achieve this feat (i.e., data which consist of both men and women), one would need to consider the following: (i) have another researcher, in this case a woman, who could assist by implementing an intervention, and collecting data that consist of female students' responses, and (ii) replicating and expanding my conceptualization to another sociocultural context.

\section{Conclusion}

The present experimental study sought to explore the impact of an eight-week intervention program (incorporating four indicators of active learning: elaborated feedback, group work, situated learning, and videos and pictures in classroom instruction,) on Saudi students' motivational constructs (i.e., self-efficacy, task value, and effort expenditure), and academic achievement in English. The findings of repeated measures ANOVA and follow-up $t$-tests revealed that the Experimental Group scored significantly higher than the Control Group on the motivational constructs and English achievement. Taken together, the results of the present study hold not only substantive, applied, and methodological implications for researchers studying motivation and active learning, but they are also relevant to educators seeking more comprehensive approaches to enhancing their students' English motivation and achievement.

\section{References}

Akbari, E., Naderi, A., Simons, R. J., \& Pilot, A. (2016). Student engagement and foreign language learning through online social networks. Asian-Pacific Journal of Second and Foreign Language Education, 1(1), 1-22. https://doi.org/10.1186/s40862-016-0006-7

Akbari, P., \& Robert-Jan, S. (2015). Autonomy, competence, and relatedness in foreign language learning through Facebook. Computers in Human Behavior, 48, 126-134. https://doi.org/10.1016/j.chb.2015.01.036

Alhawsawi, S. (2013). Investigating student experiences of learning English as a foreign language in a preparatory programme in a Saudi university (Unpublished doctoral dissertation). University of Sussex, Brighton, UK.

Alkash, K. A. M., \& Al-Dersi, Z. E. M. (2013). Advantages of using PowerPoint presentation in EFL classroom \& the status of its use in Sebha University. International Journal of English Language and Translation Studies, $1(1), 3-16$. 
Alkubaidi, M. A. (2014). The relationship between Saudi English major university students' writing performance and their learning style and strategy use. English Language Teaching, 7(4), 83-95. https://doi.org/10.5539/elt.v7n4p83

AlMaiman, I. (2005). A study of seventh-grade Saudi students' motivation level to learn English as a foreign language (Unpublished doctoral dissertation). University of Kansas, Lawrence, US.

Alrabai, F. (2014). A model of foreign language anxiety in the Saudi EFL context. English Language Teaching, 7(7), 82-101. https://doi.org/10.5539/elt.v7n7p82

Alrabai, F. (2016). Factors underlying low achievement of Saudi EFL learners. International Journal of English Linguistics, 6(3), 21-37. https://doi.org/10.5539/ijel.v6n3p21

Al-Seghayer, K. (2014). The four most common constraints affecting English teaching in Saudi Arabia. International Journal of English Linguistics, 4(5), 17-26. https://doi.org/10.5539/ijel.v4n5p17

Bandura, A. (1977). Self-efficacy: Toward a unifying theory of behavioral change. Psychological Review, 84(2), 191-215. https://doi.org/10.1037/0033-295X.84.2.191

Bandura, A. (1986). Social foundations of thought and action: A social cognitive theory. Englewood Cliffs, NJ: Prentice-Hall.

Bandura, A. (1997). Self-efficacy: The exercise of control. New York: W. H. Freeman \& Co.

Bandura, A., \& Schunk, D. H. (1981). Cultivating competence, self-efficacy, and intrinsic interest through proximal self-motivation. Journal of Personality and Social Psychology, 41(3), 586-598. https://doi.org/10.1037/0022-3514.41.3.586

Bejarano, Y. (1987). A cooperative small-group methodology in the language classroom. TESOL Quarterly, 21(3), 483-504. https://doi.org/10.2307/3586499

Berk, R. A. (2009). Multimedia teaching with video clips: TV, movies, YouTube, and mtvU in the college classroom. International Journal of Technology in Teaching and Learning, 5(1), 1-21.

Black, P., \& Wiliam, D. (1998). Assessment and classroom learning. Assessment in Education, 5(1), 7-74. https://doi.org/10.1080/0969595980050102

Bong, M. (2001). Role of self-efficacy and task-value in predicting college students' course performance and future enrollment intentions. Contemporary Educational Psychology, 26(4), 553-570. https://doi.org/10.1006/ceps.2000.1048

Bresó, E., Schaufeli, W. B., \& Salanova, M. (2011). Can a self-efficacy-based intervention decrease burnout, increase engagement, and enhance performance? A quasi-experimental study. Higher Education, 61(4), 339-355. https://doi.org/10.1007/s10734-010-9334-6

British Council. (2013). The English effect. London, UK: British Council.

Brown, H. D. (2001). Teaching by principles: An interactive approach to language pedagogy $\left(2^{\text {nd }}\right.$ ed.). White Plains, NY: Addison Wesley Longman.

Cakir, I. (2006). The use of video as an audio-visual material in foreign language teaching classroom. TOJET: The Turkish Online Journal of Educational Technology, 5(4), 67-72. Retrieved from http://search.proquest.com.ezproxy.une.edu.au/docview/1288365205?accountid=17227

Dupeyrat, C., \& Mariné, C. (2005). Implicit theories of intelligence, goal orientation, cognitive engagement, and achievement: A test of Dweck's model with returning to school adults. Contemporary Educational Psychology, 30(1), 43-59. https://doi.org/10.1016/j.cedpsych.2004.01.007

Eccles, J. S., Wigfield, A., \& Schiefele, U. (1998). Motivation to succeed. In W. Damon (series Ed.) \& N. Eisenberg (vol. Ed.), Handbook of child psychology social emotional, and personality development, 3 ( th $^{\text {th }}$ ed., pp. 1017-1095). New York: John Wiley \& Sons.

Elliot, A. J., McGregor, H. A., \& Gable, S. (1999). Achievement goals, study strategies, and exam performances: A mediational analysis. Journal of Educational Psychology, 91, 549-563. https://doi.org/10.1037//0022-0663.91.3.549

Ellis, R. (1994). The study of second language acquisition. Oxford: Oxford University Press.

Fenollar, P., Román, S., \& Cuestas, P. J. (2007). University students' academic performance: An integrative 
conceptual framework and empirical analysis. British Journal of Educational Psychology, 77(4), 873-891. https://doi.org/10.1348/000709907x189118

Fredricks, J. A., Blumenfeld, P. C., \& Paris, A. H. (2004). School engagement: Potential of the concept, state of the evidence. Review of Educational Research, 74(1), 59-109. https://doi.org/10.3102/00346543074001059

Gardner, R.C., Masgoret, A. M., Tennant, J., \& Mihic, L. (2004). Integrative motivation: Change during a year-long intermediate-level language. Language Learning, 54(1), 1-34. https://doi.org/10.1111/j.1467-9922.2004.00247.x

Gass, S. (1997). Input, interaction, and the second language learner. Mahwah, NJ: Lawrence Erlbaum.

González, A., \& Paoloni, P. V. (2015). Perceived autonomy-support, expectancy, value, metacognitive strategies and performance in chemistry: A structural equation model in undergraduates. Chemistry Education Research and Practice, 16(3), 640-653. https://doi.org/10.1039/c5rp00058k

Hamdan, M. H. (2015). The perceptions of Saudi EFL English-major students of the impact of video materials on the improvement the listening skill. International Journal of Linguistics, 7(1), 111-128. https://doi.org/10.5296/ijl.v7i1.7196

Hattie, J. A. (1999). Influences on student learning (Inaugural professorial address, University of Auckland, New Zealand). Retrieved from http://www.arts .auckland.ac.nz/staff/index.cfm?P=8650

Hattie, J., \& Gan, M. (2011). Instruction based on feedback. In R.E. Mayer \& P.A. Alexander (Eds.), Handbook of research on learning and instruction (pp. 249-71). New York, NY: Routledge.

Hattie, J., \& Timperley, H. (2007). The power of feedback. Review of Educational Research, 77(1), 81-112. https://doi.org/10.3102/003465430298487

Haverback, H. R. (2009). Facebook: Uncharted territory in a reading education classroom. Reading Today, 27(2), 34-35.

Hulleman, C. S., Durik, A. M., Schweigert, S. B., \& Harackiewicz, J. M. (2008). Task values, achievement goals, and interest: An integrative analysis. Journal of Educational Psychology, 100(2), 398-416. 10.1037/0022-0663.100.2.398

Hurt, N. E., Moss, G. S., Bradley, C. L., Larson, L. R., Lovelace, M., Prevost, L. B., ... Camus, M. S. (2012). The Facebook effect: College students' perceptions of online discussions in the age of social networking. International Journal for the Scholarship of Teaching and Learning, 6(2), 10-24. https://doi.org/10.20429/ijsotl.2012.060210

Johnson, M. L., Edwards, O. V., \& Dai, T. (2014). Growth trajectories of task value and self-efficacy across an academic semester. Universal Journal of Educational Research, 2(1), 10-18. 10.13189/ujer.2014.020102

Kabilan, M. K., Ahmad, N., \& Abidin, M. J. Z. (2010). Facebook: An online environment for learning of English in institutions of higher education? The Internet and Higher Education, 13(4), 179-187. https://doi.org/10.1016/j.iheduc.2010.07.003

Kabooha, R. H. (2016). Using movies in EFL classrooms: A study conducted at the English Language Institute (ELI), King Abdul-Aziz University. English Language Teaching, 9(3), 248-267. https://doi.org/10.5539/elt.v9n3p248

Kim, Y. (2008). The contribution of collaborative and individual tasks to the acquisition of L2 vocabulary. The Modern Language Journal, 92(1), 114-130. https://doi.org/10.1111/j.1540-4781.2008.00690.x

Koizumi, R., \& Matsuo, K. (1993). A longitudinal study of attitudes and motivation in learning English among Japanese seventh-grade students. Japanese Psychological Research 35(1), 1-11.

Kurniawan, F. (2016). The use of audio visual media in teaching speaking. English Education Journal, 7(2), 180-193.

Lave, J. (1988). Cognition in practice: Mind, mathematics and culture in everyday life. Boston, MA: Cambridge University Press.

Lave, J., \& Wenger, E. (1991). Situated learning: Legitimate peripheral participation. Cambridge: Cambridge university press.

Lee, S. P., Lee, S. D., Liao, Y. L., \& Wang, A. C. (2015). Effects of audio-visual aids on foreign language test anxiety, reading and listening comprehension, and retention in EFL learners. Perceptual and Motor Skills,120(2), 576-590. https://doi.org/10.2466/24.pms.120v14x2 
Linnenbrink, E. A., \& Pintrich, P. R. (2003). The role of self-efficacy beliefs in student engagement and learning in the classroom. Reading \& Writing Quarterly: Overcoming Learning Difficulties, 19(2), 119-137. https://doi.org/10.1080/10573560308223

Long, M. H. (1996). The role of the linguistic environment in second language acquisition. In W. R. Ritchie \& T. K. Bhatia (Eds.), Handbook of second language acquisition (pp. 413-468). San Diego, CA: Academic Press.

Long, M. H., \& Porter, P. A. (1985). Group work, interlanguage talk, and second language acquisition. TESOL Quarterly, 19(2), 207-228. https://doi.org/10.2307/3586827

Martin, A. J. (2005). Exploring the effects of a youth enrichment program on academic motivation and engagement. Social Psychology of Education, 8(2), 179-206. 10.1007/s11218-004-6487-0

Martin, A. J. (2008). Enhancing student motivation and engagement: The effects of a multidimensional $\begin{array}{llll}\text { intervention. Contemporary } & \text { Educational } & \text { Psychology, } & 33(2),\end{array}$ https://doi.org/10.1016/j.cedpsych.2006.11.003

Martin, A. J., Way, J., Bobis, J., \& Anderson, J. (2015). Exploring the ups and downs of mathematics engagement in the middle years of school. The Journal of Early Adolescence, 35(2), 199-244. https://doi.org/10.1177/0272431614529365

Mathew, N. G., \& Alidmat, A. O. H. (2013). A study on the usefulness of audio-visual aids in EFL classroom: Implications for effective instruction. International Journal of Higher Education, 2(2), 86-92. https://doi.org/10.5430/ijhe.v2n2p86

McCormick, C. (2013). Countries with better English have better economies. Harvard Business Review. Retrieved from https://hbr.org/2013/11/countries-with-better-english-have-better-economies.

Moghadam, A. R., \& Talafian, H. (2015). Power point presentation and Iranian high school EFL learners' grammatical knowledge and interest. International Journal of Education and Research, 3(4), 61-74.

Nikbakht, E., \& Boshrabadi, A. M. (2015). Analysing the potential of social networking sites on EFL learners' vocabulary mastery: A situated-learning approach. Theory and Practice in Language Studies, 5(8), 1635-1641. https://doi.org/10.17507/tpls.0508.13

Omar, H., Embi, M. A., \& Yunus, M. M. (2012). ESL learners' interaction in an online discussion via Facebook. Asian Social Science, 8(11), 67-74. https://doi.org/10.5539/ass.v8n11p67

Pajares, F., \& Kranzler, J. (1995). Self-efficacy beliefs and general mental ability in mathematical problem-solving. Contemporary Educational Psychology, 20(4), 426-443. https://doi.org/10.1006/ceps.1995.1029

Pajares, F., \& Miller, M. D. (1994). Role of self-efficacy and self-concept beliefs in mathematical problem solving: A path analysis. Journal of Educational Psychology, 86(2), 193-203. 10.1037/0022-0663.86.2.193

Phan, H. P. (2011). Interrelations between self-efficacy and learning approaches: A developmental approach. Educational Psychology, 31(2), 225-246. https://doi.org/10.1080/01443410.2010.545050

Phan, H. P. (2012). Prior Academic achievement, effort, and achievement goal orientations: A longitudinal examination. Journal of Educational and Developmental Psychology, 2(2), 57-71. https://doi.org/10.5539/jedp.v2n2p57

Phan, H. P. (2013). The capitalization of personal self-efficacy: Yields for practices and research development. Journal of Educational and Developmental Psychology, 3(1), 72-87. https://doi.org/10.5539/jedp.v3n1p72

Phan, H. P. (2014). Interrelations that foster learning: An investigation of two correlational studies. International Journal of Psychology, 51(3), 185-195. https://doi.org/10.1002/ijop.12127

Phan, H. P., \& Ngu, B. H. (2017). Undertaking experiments in social sciences: Sequential, multiple time series designs for consideration. Educational Psychology Review. doi:10.1007/s10648-016-9368-0

Pintrich, P. R., \& Schunk, D. H. (2002). Motivation in education: Theory, research, and applications ( $2^{\text {nd }}$ ed.). Englewood Cliffs, NJ: Prentice Hall.

Rajab, H. (2013). Developing speaking and writing skills of L1 Arabic EFL learners through teaching of IPA phonetic codes. Theory and Practice in Language Studies, 3(4), 653-659. https://doi.org/10.4304/tpls.3.4. 653-659

Razak, N. A., Saeed, M., \& Ahmad, Z. (2013). Adopting Social Networking Sites (SNSs) as interactive communities 
among English Foreign Language (EFL) learners in writing: Opportunities and challenges. English Language Teaching, 6(11), 187-198. https://doi.org/10.5539/elt.v6n11p187

Riviere, A. (1997). Feedback: Enhancing the Performance of Adult Learners with Learning Disabilities. Washington, DC: National Adult Literacy and Learning Disabilities Centre.

Schunk, D. H. (1982). Effects of effort attributional feedback on children's perceived self-efficacy and achievement. Journal of Educational Psychology, 74(4), 548-565. https://doi.org/10.1037/0022-0663.74.4.548

Schunk, D. H., Hanson, A. R., \& Cox, P. D. (1987). Peer-model attributes and children's achievement behaviors. Journal of Educational Psychology, 79(1), 54-61. 10.1037/0022-0663.79.1.54

Shah, P., \& Freedman, E. G. (2003). Visuospatial cognition in electronic learning. Journal of Educational Computing Research, 29(3), 315-324. https://doi.org/10.2190/qyvj-q591-ve7c-ehuv

Shim, S., \& Ryan, A. (2005). Changes in self-efficacy, challenge avoidance, and intrinsic value in response to grades: The role of achievement goals. Journal of Experimental Education, 73(4), 333-349. https://doi.org/10.3200/jexe.73.4.333-349

Slavin, R. E. (1994). Using student team learning (4 ${ }^{\text {th }}$ ed.). Baltimore: Johns Hopkins Team Learning Project.

Storch, N. (2005). Collaborative writing: Product, process, and students' reflections. Journal of Second Language Writing, 14(3), 153-173. https://doi.org/10.1016/j.jslw.2005.05.002

Storch, N. (2007). Investigating the merits of pair work on a text editing task in ESL classes. Language Teaching Research, 11(2), 143-159. https://doi.org/10.1177/1362168807074600

Susskind, J. E. (2008). Limits of PowerPoint's power: Enhancing students' self-efficacy and attitudes but not their behavior. Computers \& Education, 50(4), 1228-1239. https://doi.org/10.1016/j.compedu.2006.12.001

Suthiwartnarueput, T., \& Wasanasomsithi, P. (2012). Effects of using Facebook as a medium for discussions of English grammar and writing of low-intermediate EFL students. Electronic Journal of Foreign Language Teaching, 9(2), 194-214.

Tachibana, Y., Matsuoka, R., \& Zhong, Q. X. (1996). Attitudes and motivation for learning English: A cross-sectional comparison of Japanese and Chinese high school students. Psychological Reports, 79(2), 691-700. https://doi.org/10.2466/pr0.1996.79.2.691

Tanielian, A. R. (2017). Foreign language anxiety among first-year Saudi university students. International Education Journal: Comparative Perspectives, 16(2), 116-130.

Ur Rahman, M. M., \& Alhaisoni, E. (2013). Teaching English in Saudi Arabia: Prospects and challenges. Academic Research International, 4(1), 112-118.

Wang, M. T., \& Eccles, J. S. (2013). School context, achievement motivation, and academic engagement: A longitudinal study of school engagement using a multidimensional perspective. Learning and Instruction, 28, 12-23. https://doi.org/10.1016/j.learninstruc.2013.04.002

Wang, S. L., \& Wu, P. Y. (2008). The role of feedback and self-efficacy on web-based learning: The social cognitive perspective. Computers \& Education, 51(4), 1589-1598. 10.1016/j.compedu.2008.03.004

Wigfield, A., \& Eccles, J. S. (1992). The development of achievement task values: A theoretical analysis. Developmental Review, 12(3), 265-310. 10.1016/0273-2297(92)90011-P

Wigfield, A., \& Eccles, J. S. (2000). Expectancy-value theory of achievement motivation. Contemporary Educational Psychology, 25(1), 68-81. 10.1006/ceps.1999.1015

Yuksel, D., \& Tanriverdi, B. (2009). Effects of watching captioned movie clip on vocabulary development of EFL learners. TOJET: The Turkish Online Journal of Educational Technology, 8(2), 48-56.

Yunus, M. M., \& Salehi, H. (2012). The effectiveness of Facebook groups on teaching and improving writing: Students' perceptions. Journal of Education and Information Technologies, 1(6), 87-96.

Zimmerman, B. J., \& Risemberg, R. (1997). Self-regulatory dimensions of academic learning and motivation. In E. Phye (Eds.), Handbook of academic learning (pp. 105-125). New York: Academic Press. 